\title{
National Character Education Policy in Law Number 23 of 2019
}

\author{
Muria Putriana', Matin², Sugiarto3, Tjetjep Darmawan4 \\ DOI: 10.35445/alishlah.v13i2. 636
}

\section{Article Info \\ Keywords: \\ Character Value; \\ Education ; \\ Nation Defence; \\ Law}

Kata kunci:

Nilai Karakter;

Pendidikan;

Pertahanan Bangsa;

Undang-undang

\begin{abstract}
The study aimed to understand the value of national character education in Law number 23 of 2019. The policy of developing character values through the Act is related to strengthening national character. The method used qualitative descriptive. Data were collected through observation, interviews, and documentation. At the same time, the data analysis technique is presented in the form of narrative text through procedures, namely coding, data reduction, data presentation, data triangulation, drawing conclusions, and data analysis. The results show that there are thirteen character education values found in Law number 23 of 2019. Eleven character values are relevant to the character values conceptualized in the Indonesian education curriculum, and two new values are the values of patriotism and the spirit of Pancasila. The implications found are related to understanding the concept of character values by the diversity of Indonesian society
\end{abstract}

\begin{abstract}
Abstrak
Penelitian ini bertujuan untuk memahami nilai pendidikan karakter nasional dalam Undang-undang nomor 23 tahun 2019. Kebijakan pengembangan nilai karakter melalui Undang-undang tersebut terkait dengan penguatan karakter kebangsaan. Metode yang digunakan adalah kualitatif descriptive. Data dikumpulkan melalui observasi, wawancara dan dokumentasi. Sedangkan teknik analisis data disajikan dalam bentuk teks narasi melalui prosedur yaitu coding, reduksi data, penyajian data, triangulasi data, penarikan simpulan dan analisis data. Hasil penelitian menunjukkan bahwa ada tiga belas nilai pendidikan karakter yang ditemukan dalam Undang-undang nomor 23 tahun 2019. Sebelas nilai karakter relevan dengan nilai karakter yang dikonsepkan pada kurikulum pendidikan Indonesia dan dua nilai baru yang ditemukan adalah nilai patriotism dan jiwa Pancasila. Adapun implikasi yang ditemukan terkait dengan pemahaman konsep nilai karakter yang sesuai dengan keragaman masyarakat Indonesia.
\end{abstract}

\footnotetext{
${ }^{1}$ Universitas Negeri Jakarta, Indonesia

Email: muriaputriana@gmail.com

${ }^{2}$ Universitas Negeri Jakarta, Indonesia

Email: matin.unj@gmail.com@gmail.com

3 Universitas Negeri Jakarta, Indonesia

Email: sugiarto63sutomo@gmail.com

4 Kementerian Pertahanan, Indonesia

Email: tjdarmawano66@gmail.com
} 


\section{INTRODUCTION}

Human life-changing marked by advances in science and technology have led everyone to face global competition. In this case, every nation must be ready to face these global challenges. Therefore, the essential part of preparing a quality society is through the educational process. One part of human development is oriented to the development of science, but soft skills are a significant segment of life. Article 3 of the Constitution Number 23 concerning the National Education System states that National Education functions to develop capabilities and shape the character and civilization of a dignified nation in the context of the nation's intellectual life. As for students, according to article 1 paragraph 4 , are community members who are trying to develop their potential through the learning process available on the path, level, and type of education.

To realize the life of a civilized nation, one of the efforts made is to develop character education policies. In Presidential Regulation Number 87 of 2017, it is stated that strengthening character education is an educational movement under the responsibility of the education unit to strengthen the character of students through harmonization of feel, taste, thought, and sports activities with involvement and cooperation between education units, families, and society (Hasnidar \& Elihami, 2019; Komariah \& Satori, 2021) as part of the National Movement for Mental Revolution. One of the critical implementation points mentioned in Article 2 is the government's earnest effort to revitalize and strengthen the potential and competence of various elements in the education ecosystem.

Observations show that currently, the issue of character or morals is not entirely ignored. However, the phenomenon shows that there is instability to grow the Indonesian nation with character and fix the current decline in the character of the Indonesian nation. There should be a national strategic policy to grow the community, especially the younger generation, who have excellent and civilized character. Therefore, the government and related stakeholders have drafted the Law of the Republic of Indonesia Number 23 of 2019 concerning the Management of National Resources for National Defense. It is a national strategic policy that has been ratified to transform human resources, natural resources, artificial resources, and national facilities and infrastructure into national defence forces through a forum for fostering awareness of defending the country by instilling five basic values of defending the country. It supports the strengthening of the nation's character to create excellent resources and unify the vision and mission of national development.

There were strengthening national character education by instilling the five fundamental values of defending the country as intended, including love for the homeland, awareness of the life of the nation and state, loyalty to Pancasila, willingness to sacrifice, and the ability to defend the country. Thus, it can be said that the implementation of Law Number 23 of 2019 concerning Management of National Resources for National Defense is a subsystem of the implementation of state defence which also supports the Strengthening of Character Education of the Indonesian Nation. The development of character education is inseparable from the social and political dynamics of the Indonesian nation. Character education is always used as a tool by the authorities to support the status quo of the rulers. Character education is not done to build students' character so that they have strong personalities, integrity, honesty, advocate for the poor, marginalized, minorities, have high solidarity, tolerance, respect diversity, and another noble character (Husni, 2020; Cafo, 2000).

Character education development occurs in schools or educational institutions, but all parties must carry out the character education process. The Ministry of Defense has realized the development of character education through the socialization of Law Number 23 of 2019 to support the Strengthening of National Character Education. It aims to build continuity and synergy by the roles and functions of each stakeholder as a strategic coaching partner in unifying the vision and mission of national development. Therefore, this research needs to be carried out as a form of urgency in developing character education from participants' perceptions in the education and training of the State Defense Education and Training Center of the Ministry of Defense of the Republic of Indonesia. 
Many studies related to character education have been studied through teaching and learning in school. So, teachers are required to have qualified competence in developing character education (Ülger, Yiğittir, \& Ercan, 2014; Julia \& Supriyadi, 2018). The transformation of character education for students in an effort to face 21st-century education or Industrial revolution 4.0 (Dewia \& Alam, 2020). It has an impact on the quality of national resources. In addition, education is considered the best thing to prepare agents of national change who will bring prosperity to society (Rokhman, Hum, Syaifudin, \& Yuliati, 2014). Schools can design the concept of character learning specifically (Birhan, Shiferaw, Amsalu, Tamiru, \& Tiruye, 2021) because it can impact social life (Cheung \& Lee, 2010). The Indonesian government has implemented it in the 2013 curriculum (Fahmy, Bachtiar, Rahim, \& Malik, 2015) that explains some value of character related to Law number 23 of 2019.

Thus, this research focuses on understanding the character education policies contained in Law Number 23 of 2019, managed by the State Defense agency. The process of character education is mostly carried out by educational institutions associated with achieving educational goals. However, this study has a different orientation because 1) character education already has achievement standards related to strengthening the nation's character. 2) character education must be carried out by all parties or all Indonesian people. 3) Character education must be implemented in the context related to National Resource Management for National Defense. 4) In-depth understanding of Law number 23 of 2019 must be widely understood in building the nation.

So, this study aims to explore students' perceptions at the State Defense Education and Training Center of the Ministry of Defense of the Republic of Indonesia regarding character education in Law number 23 of 2019. This research is expected to contribute to the development of character education adapted from Law number 23 of 2019 for all elements of society.

\section{METHODS}

The study used a qualitative approach through the survey. It explores the phenomenon of the character education value from Law Number 23 of 2019. It was conducted in the education and training centre for the State Defense Ministry of Defense of the Republic of Indonesia, Rumpin Bogor. Data collection techniques used observation, interviews, focus group discussions, and documentation. The observations are done to analyze participant's information on character education implemented in Law Number 23 of 2019. Interviews were conducted with the Head of the National Defense Education and Training Center, the Head of the Sub-Directorate for State Defense, Widyaiswara, and Instructors, participants in the training of state defence and state defence cadres. There are 20 participants. The researcher also chose to use focus group discussions in concluding data related to the participants' perceptions in providing perceptions of character education from the implementation of Law Number 23 of 2019.

The qualitative data analysis technique was carried out interactively and took place continuously until it was completed so that the data was saturated. The stages of data analysis techniques are;

\section{Data Reduction}

Data reduction is done by summarizing, choosing the main things, focusing on the important things, and looking for themes and patterns to eliminate the unnecessary. Thus, the reduced data will provide a clear picture and make it easier for researchers to conduct further data collection and look for it when needed. In this study, the data that has been obtained from the results of interviews, observations, discussions and documentation are summarized and selected according to the values of character education that have been built by Law Number 23 of 2019

2. Data Presentation

The data that has been sorted and summarized is then presented in the form of narrative text in the research on the Implementation of Law Number 23 of 2019 concerning Management of National Resources for National Defense in supporting the Strengthening of National Character Education at the Ministry of Defense's National Defense Education and Training Center. 


\section{Data triangulation/Data validity}

In this study, the triangulation method used by the researcher is checking through predetermined sources and comparing and checking back the degree of confidence in information obtained from different sources. At this stage, the data that has been presented is then checked again for the validity of the data through forum group discussion activities and repeated checking of the data that has been obtained previously.

4. Drawing Conclusion

The last step is drawing conclusions and verification. According to the researcher, the initial conclusions are still temporary and will change if no substantial evidence supports the next stage of data collection.

\section{Theme Analysis}

Furthermore, the researchers conducted a theme analysis between the results of data analysis and the results of interviews. According to the researcher, the results of the analysis and interviews found different results from the initial conclusions of the researchers. So that when the analysis on the Implementation of Law Number 23 of 2019 concerning Management of National Resources for National Defense in supporting the Strengthening of National Character Education has been completed, researchers have been able to get a clear picture of the existing problems.

\section{FINDINGS AND DISCUSSION}

The results of data analysis show that Law number 23 of 2019, which has been implemented in the education and training process at the State Defense Education and Training Center of the Ministry of Defense of the Republic of Indonesia, is closely related to national values. These values have also been taught and included in the educational curriculum. The character values that emerge from the participants' perceptions are:

\section{Table 1. Character Value}

\begin{tabular}{|c|c|c|}
\hline $\begin{array}{c}\text { Law number } 23 \text { of } \\
2019\end{array}$ & Finding & $\begin{array}{c}\text { Implemented Character Value in } \\
\text { Education Curriculum (Ministry } \\
\text { National Education) }\end{array}$ \\
\hline $\begin{array}{l}\text { Management of National } \\
\text { Resources for National } \\
\text { Defense in Support of } \\
\text { Strengthening National } \\
\text { Character Education at the } \\
\text { State Defense Education } \\
\text { and Training Center of the } \\
\text { Ministry of Defense of the } \\
\text { Republic of Indonesia }\end{array}$ & $\begin{array}{l}\text { Honest, } \\
\text { Tolerance, } \\
\text { Discipline } \\
\text { Hard Work, } \\
\text { Democratic, } \\
\text { Spirit Of Nationality, } \\
\text { Motherland Love, } \\
\text { Love Peace, } \\
\text { Friendly/Communicative. } \\
\text { Environmental Care } \\
\text { Responsibility } \\
\text { Patriotism } \\
\text { Spirit of Pancasila }\end{array}$ & $\begin{array}{l}\text { Religious. } \\
\text { Honest. } \\
\text { Tolerance. } \\
\text { Discipline. } \\
\text { Hard work. } \\
\text { Creative. } \\
\text { Independent. } \\
\text { Democratic. } \\
\text { Curiosity. } \\
\text { Spirit of nationality. } \\
\text { Motherland Love. } \\
\text { Appreciate Achievement. } \\
\text { Friendly/Communicative. } \\
\text { Love peace. } \\
\text { I like to read. } \\
\text { Environmental care. } \\
\text { Social care. } \\
\text { Responsibility. }\end{array}$ \\
\hline
\end{tabular}

Table 1 concludes that the character education taught in Law Number 23 of 2019 is related to the concept of defending the country, namely love for the homeland. The values contained teach that the millennial generation is required to have care and a sense of patriotism. It becomes the basis as a nation's strength or resource from the community in defending the state's interests. Through various training activities, the government has implemented Law number 23 of 2019 because the guidance and direction have also been directed at improving skills for the future. This means that this character value is beneficial in complementing the skills and knowledge of the next generation. 
It will be a success if the teacher or trainer know their role in the learning process (Lickona, 1997) and they know the reform of education institution (Chang et al., 2013)

The majority of people accept the existence of the national resource management movement to form the nation's character. From the results of interviews and discussions, it is known that the socialized values regarding Law number 23 of 2019 include; 1) scouting movement to students at district level schools, 2) cultural arts activities by participating in preserving culture in their respective areas, socializing character values through social media. The results of the socialization that have been carried out have been very good where they invite colleagues who are active in social media and influencers as well as community and religious leaders to participate in this socialization so that they can touch all levels of society and are easier to accept because they are the people closest to them. 3) Hold webinars or zoom meetings to socialize

The data finding is relevant to the character value included in the curriculum for primary school until college. All educational subjects have character education values taught in the hidden curriculum (Abdullah, 2019; Suherman, Supriyadi, \& Cukarso, 2019; Suherman, 2018; Miftakhu Rosyad \& Wiralodra Indramayu, 2020). It means that the concept of character education in Law number 23 of 2019 is in line with the concept of character education launched by the Indonesian Ministry of Education. The findings of these eleven character values are part of what has been described in the learning curriculum for elementary school to university. However, educational institutions have added other character values such as religious, creative, Independent, Curiosity, Appreciate Achievement, like to read, and Social Care. However, other character value finding is patriotism and having Pancasila soul. All generations must comprehend how to implement the patriotism element for the nation / Indonesia through Pancasila values. Also, the character value can implement with the comprehending culture, because the actualization of culture describes the uniqueness of society value (Rosyad \& Zuchdi, 2018) and society's morals (Althof \& Berkowitz, 2006).

Moreover, this Law was formed with good intentions for the community to strengthen the national character of the defence of the state, of course. With the establishment of this Law in the future, it will become a guideline for the community always to carry out state defence in the community. In addition, every citizen has the right and is obliged to participate in national defence and security efforts. The implementation of Law Number 23 of 2019 concerning Management of National Resources for National Defense aims to equip resources with the spirit of Pancasila in the face of the dynamics of changing times to guarantee future users in realizing the national vision and mission in supporting the strengthening of character education for the Indonesian nation. This Law is perfect. It has shown the process of strengthening character education which aims to build and equip resources with the spirit of Pancasila in facing the dynamics of change in the future because holding character education on nationality will strengthen the young generation who are currently starting to lose their national spirit and defend their country free life

Law Number 23 of 2019 concerning Management of National Resources for National Defense in supporting Strengthening National Character Education provides a positive contribution for state defence training participants, especially the younger generation is facing the era of industrial technology development 4.o. The development of character education has been carried out through fostering awareness of defending the country. Our potential as a nation that has many human and natural resources must be maximized. This is where the role of education in shaping the character of the nation will be able to become a great country, with all the potential it has so that the Indonesian nation is ready to face all forms of threats and create people with character and excellence to participate in the progress of the Indonesian state. In-Law no.23 of 2019 shows that the government has directed character education for the nation's progress (Was, Woltz, \& Drew, 2006). It was relevant to the role in character education for school. It develops morals and democracy for societies (Althof \& Berkowitz, 2006). 


\section{CONCLUSION}

The finding concluded that Law number 23 of 2019 presented the character values related to the curriculum in the school and college. The Ministry of Defense at the National Defense Education and Training Center has given to the public that defending the country is not mandatory in the military, but defending the country is a right and obligation as citizens to jointly maintain the country's integrity. Thus, the implementation of Law Number 23 of 2019 concerning the Management of National Resources in supporting the Strengthening of National Character Education in the face of the dynamics of changing times. It can strengthen the nation's spirit so that the implementation of Law Number 23 of 2019 concerning Management of National Resources for National Defense can minimize the urgency of the current national character problem and guarantee future users in realizing the national vision and mission in supporting strengthening national charactered.

This research has implications for people's understanding of character education values from Law number 23 of 2019. The diversity of society creates a diversity of interests so that the values of the nation's character in the Law can unite the soul of the Indonesian people to love the homeland. In addition, this model of character values is also relevant to current needs, which have also been applied for formal educational institutions. However, this research has limitations because it only focuses on the value of national character in Law number 23 of 2019. So, this research can still be developed on combining the meaning of the context of character education with the Law that examines national education.

\section{REFERENCES}

Abdullah. (2019). Beyond School Reach: Character Education in Three Schools in Yogyakarta, Indonesia. Journal of Educational and Social Research, 9(3), 145-159. Retrieved from https://www.mcser.org/journal/index.php/jesr/article/view/10497

Althof, W., \& Berkowitz, M. W. (2006, December 1). Moral education and character education: Their relationship and roles in citizenship education. Journal of Moral Education. https://doi.org/10.1080/03057240601012204

Birhan, W., Shiferaw, G., Amsalu, A., Tamiru, M., \& Tiruye, H. (2021). Exploring the context of teaching character education to children in preprimary and primary schools. Social Sciences \& Humanities Open, 4(1), 100171. https://doi.org/10.1016/j.ssaho.2021.100171

Cafo, Z. D. (2000). Global Values in Education and Character Education. Retrieved from https://eric.ed.gov/?id=ED449449

Chang, M. C., Shaeffer, S., Al-Samarrai, S., Ragatz, A. B., de Ree, J., \& Stevenson, R. (2013). Teacher Reform in Indonesia: The Role of Politics and Evidence in Policy Making. Teacher Reform in Indonesia: The Role of Politics and Evidence in Policy Making. The World Bank. https://doi.org/10.1596/978-0-8213-9829-6

Cheung, C. kiu, \& Lee, T. yan. (2010). Improving social competence through character education. Evaluation and Program Planning, 33(3), 255-263. https://doi.org/10.1016/j.evalprogplan.2009.08.006

Dewia, E. R., \& Alam, A. A. (2020). Transformation model for character education of students. Cypriot Journal of Educational Sciences, 15(5), 1228-1237. https://doi.org/10.18844/cjes.v15i5.5155

Fahmy, R., Bachtiar, N., Rahim, R., \& Malik, M. (2015). Measuring Student Perceptions to Personal Characters Building in Education: An Indonesian Case in Implementing New Curriculum in High School. Procedia - Social and Behavioral Sciences, 211, 851-858.

https://doi.org/10.1016/j.sbspro.2015.11.112

Hasnidar, H., \& Elihami, E. (2019). The management Model of National Character Education for Early Childhood Education through based on Democracy. Edumaspul - Jurnal Pendidikan, 3(1), 15-19. https://doi.org/10.33487/edumaspul.v3i1.75 
Husni, H. (2020). CHARACTER EDUCATION IN INDONESIA: A HISTORICAL OUTLOOK. Educational Review: International Journal, 17(1), 147-162. Retrieved from https://fsshjournal.org/index.php/es/article/view/132

Julia, \& Supriyadi, T. (2018). The Implementation of Character Education at Senior High School. SHS Web of Conferences, 42, o0085. https://doi.org/10.1051/shsconf/20184200085

Komariah, A., \& Satori, an. (2021). Character Education in Home Based Learning During COVID-19 Pandemic. Atlantis Press. https://doi.org/10.2991/ASSEHR.K.210212.037

Lickona, T. (1997). The Teacher's Role in Character Education. Journal of Education, 179(2), 638o. https://doi.org/10.1177/002205749717900206

Miftakhu Rosyad, A., \& Wiralodra Indramayu, U. (2020). Internalization of character education based on Islamic values to students at SMK Muhammadiyah Juntinyuat. Islam in World Perspectives Symposium, 1(1), 273-285. https://doi.org/10.26555/iwos.v1i1.5726

Rokhman, F., Hum, M., Syaifudin, A., \& Yuliati. (2014). Character Education for Golden Generation 2045 (National Character Building for Indonesian Golden Years). Procedia Social and Behavioral Sciences, 141, 1161-1165. https://doi.org/10.1016/J.SBSPRO.2014.05.197

Rosyad, A. M., \& Zuchdi, D. (2018). Aktualisasi pendidikan karakter berbasis kultur sekolah dalam pembelajaran IPS di SMP. Harmoni Sosial: Jurnal Pendidikan IPS, 5(1), 79-92. https://doi.org/10.21831/hsjpi.v5i1.14925

Suherman, A. (2018). The Implementation Of Character Education Values In Integrated Physical Education Subject In Elementary School. SHS Web of Conferences, 42, 00045. https://doi.org/10.1051/shsconf/20184200045

Suherman, A., Supriyadi, T., \& Cukarso, S. H. I. (2019). Strengthening national character education through physical education: An action research in Indonesia. International Journal of Learning, Teaching and Educational Research, 18(11), 125-153. https://doi.org/10.26803/ijlter.18.11.8

Ülger, M., Yiğittir, S., \& Ercan, O. (2014). Secondary School Teachers' Beliefs on Character Education Competency. Procedia - Social and Behavioral Sciences, 131, 442-449. https://doi.org/10.1016/J.SBSPRO.2014.04.145

Was, C. A., Woltz, D. J., \& Drew, C. (2006). Evaluating character education programs and missing the target: A critique of existing research. Educational Research Review, 1(2), 148-156. https://doi.org/10.1016/j.edurev.2006.08.001 